\title{
Examination of Disputes between the National Library of Korea and the National Assembly Library
}

\author{
RYU Hyeonsook ${ }^{*}$
}

\begin{abstract}
There exist two national libraries in Korea: the National Library of Korea (NLK) and the National Assembly Library (NAL). Given that both libraries perform the national library function, debates on their unification began in the 1950s and continued up until the mid1970s. Even in the $21^{\text {st }}$ century, disputes pertaining to the exclusive use of the title national representative library continue between the two libraries. This paper examines the disputes between the two national libraries of Korea from the beginning of the library legislation activities of the 1950s up to the present time.
\end{abstract}

Keywords: national library, library act, Korea, National Assembly Library, National Central Library

\section{Izvleček}

V Koreji obstajata dve nacionalni knjižnici, to sta Narodna knjižnica Koreje in Knjižnica državnega zbora. Glede na to, da obe knjižnici izvajata funkcije nacionalne knjižnice, so se v 50. letih 20. stoletja začele razprave o njuni združitvi, ki so trajale do sredine 70. let. Tudi v 21. stoletju se spori v zvezi z izključno uporabo naziva narodna predstavniška knjižnica med kjižnicama nadaljujejo. Članek proučuje spore med dvema korejskima nacionalnima knjižnicama od 50. let 20. stoletja, ko so se pričele aktivnosti za ureditev bibliotekarske zakonodaje, do današnjega dne.

Ključne besede: nacionalna knjižnica, zakon o knjižnicah, Koreja, Knjižnica državnega zbora, Nacionalna centralna knjižnica

\footnotetext{
* Hyeonsook RYU, MA, lecturer, Department of Asian and African Studies, Faculty of Arts, University of Ljubljana, Slovenia. hyeonsook.ryu@guest.arnes.si
} 


\title{
Introduction
}

\section{Purpose}

The National Libraries Section of IFLA (The International Federation of Library Associations and Institutions) is in charge of matters concerning the functions of national libraries.

\begin{abstract}
National libraries have special responsibilities, often defined in law, within a nation's library and information system. These responsibilities vary from country to country but are likely to include: the collection via legal deposit of the national imprint (both print and electronic) and its cataloguing and preservation; the provision of central services (e.g., reference, bibliography, preservation, lending) to users both directly and through other library and information centres; the preservation and promotion of the national cultural heritage; acquisition of at least a representative collection of foreign publications; the promotion of national cultural policy; and leadership in national literacy campaigns. (IFLA National Libraries Section 2014)
\end{abstract}

In Korea, two national libraries fulfil most of the conditions described above. One of these is the National Library of Korea and the other is the National Assembly Library. Administratively, the National Library of Korea is affiliated with the Ministry of Culture, Sports and Tourism, while the National Assembly Library is affiliated with the National Assembly.

Despite other existing examples of one country having two national libraries, the purpose of this paper is to examine the background and breakdown of attempts to unify the two national libraries in Korea, a country where the process of modernisation was delayed. The article further examines relations between both libraries and government institutions in the context of their disputes, as evidenced from documentation stemming from law revision periods.

\section{Definition of Terms and Representations}

In this paper, the following terminology is used.

- National library is a library established and funded by a national government with the designation "national", to serve the needs of this government, often to function as a library of record for the nation's publishing output, and in some cases 
to act as a central agency for library and bibliographic development in the nation ${ }^{1}$. (Dictionary 2014)

- The National Library of Korea, NLK: is a national library affiliated with the Korean Ministry of Culture, Sports and Tourism. It was established in 1945 and was officially renamed the National Central Library of Korea with the enactment of the Libraries Act in 1963. Due to the library having used the English language designation of National Library of Korea since 1995, this term will also be applied throughout this paper (hereinafter referred to as NLK).

- National Assembly Library, NAL: is the library established by the Korean National Assembly in 1952 (hereinafter referred to as NAL). The NAL Act was enacted in 1963.

- gugga (국가, 國家) and guglib (국립, 國立) ${ }^{2}$ : are most often used to signify national when translating into the Korean language ${ }^{3}$. Gugga essentially represents the country itself, or the entire country, and is used when referring to the country as a whole. Guglib specifically indicates the fact that an institute has been founded by the state and since it expresses the circumstance of having been established and managed by the state, the term is usually applied to government funded organisations.

The above listed national library definition of "a library established and funded by a national government with the designation national" coincides with that of the guglib library and "to serve the needs of this government, often to function as a library of record for the nation's publishing output, in some cases to act as a central agency for library and bibliographic development in the nation" coincides with that of the gugga library.

\footnotetext{
${ }^{1}$ National library. Dictionary.com. Dictionary.com Unabridged. Random House, Inc.

${ }^{2} \cdot$ Guglib, national is a Chinese-like word of Japanese origin, considered to have entered the Korean language during the Japanese imperial period. Its use spread during the post-war period, when prefectural institutions and agencies were taken over from Japan. It appears that the shift to national occurred quite naturally, the detailed history of which may be examined on another occasion.

-This paper follows the "Romanization of Korean" as specified in Notification No. 2008-2 of the Ministry of Culture and Tourism. (8) "When it is necessary to convert Romanized Korean back to Hangeul in special cases such as in academic articles, Romanization is done according to Hangeul spelling and not pronunciation. Each Hangeul letter is Romanized as explained in section 2 except that ᄀ, ᄃ, $ᄇ$, ᄅ are always written as $\mathrm{g}, \mathrm{d}, \mathrm{b}, 1$. When $O$ has no sound value, it is replaced by a hyphen, which may also be used when it is necessary to distinguish between syllables."

${ }^{3}$ National may also be translated as jeongug (전국, 全國), hangug (한국, 韓國), gugnae (국내, 國 内) and other terms.
} 
To emphasize, "in some cases to act as a central agency for library and bibliographic development in the nation", jungang (중앙, 中央) is added to the name, resulting in guglib or gugga central library.

The distinction between the application of terms gugga and guglib may further be explained using the following examples. Gugga policy, "the policies of a national government" (OED), gugga language, "a language spoken by a large proportion of the inhabitants of a nation; an official language in a particular nation, typically recognized and adopted by government or in legislature government" (OED), other collocations include gugga security, gugga examination. It is incorrect to express these phrases using guglib; therefore it is uncommon to use the designation guglib policy, guglib language, guglib security or guglib examination.

Judicial, legislative and administrative institutions established for the purpose of implementing national policy are gugga institutions. Institutions and organizations established by this type of gugga institution are guglib institutions and organisations; these include guglib university, guglib museum, guglib park and others. It is incorrect to make reference to gugga university, gugga museum or gugga park.

In other words, guglib incorporates the meaning of having been established and managed by the state, while the meaning of the state as a whole is signified by the use of the term gugga. Accordingly, that the guglib library and the guglib central library were established by the state evidently influences the role that gugga library and gugga central library have in relation to other libraries across the country. This paper uses the expressions guglib library, guglib central library, gugga library, gugga central library to differentiate among national libraries, depending on the relevant context.

- gugga representative library (국가대표도서관, 國家代表圖書館): is an expression for the national representative library, a representative library of the state. This expression has recently enjoyed broad use in Korea. In an environment where multiple national libraries co-exist, the use of guglib central library and gugga central library appeared in order to indicate the central component of each of the two libraries, while gugga representative library is used to emphasize the existence of the representative role itself. 


\section{Research Method and Previous Research}

Previous research pertaining to NLK and NAL predominantly deals with their history, organisation, function, role, service contents and evaluation; it also includes examples that compare their functions with those of foreign national libraries operating on the basis of having the same or similar roles. Despite longstanding disagreements between the two institutions, the author of this research was unable to find a study assessing the disputes between the libraries. Articles do, however, compare current NLK and NAL functions in relation to the enactment and revision of library legislation that was passed in order to prompt their unification. In recent years, a number of studies concentrating on network cooperation and sharing have been undertaken.

In order to examine the disputes between NLK and NAL, this paper focuses on bulletins and reviews published by both libraries and analyses the journals of the Korean Library Association as well as other relevant journals, research reports, library legislation and library legislation proposals that have been published on this topic.

Lee Chul $\mathrm{Kyu}^{4}$ has examined the history, organisation and functioning of Japanese, American and Australian national libraries, arguing for the necessity of a guglib central library in Korea. He believes it more plausible to develop a guglib central library if both national libraries were integrated and affiliated with the National Assembly. Further to this idea, he proposed the creation of the "Draft Bill of Korean National Central Library". (Lee, C. K. 1962)

Lee Bong Sun argues that Korea should also set up a unified national library system, thus avoiding work overlap among multiple institutions while allowing them to share burdens amongst each other and prevent national loss. (Lee, B. S. 1980)

Lee, P. J. compares the current situations of NLK and NAL, asserting that a national library centred on NAL would serve as a better option. He proposes that the following be fulfilled prior to the establishment of a national library: the constitution of a National Library Committee and the formation of an integrated system, simplified in such a way as exists in the American Library of Congress.

\footnotetext{
${ }^{4}$ Lee Chul Kyu (1962) and Supreme Council for National Reconstruction (1962) are the same. (It is believed that the Supreme Council for National Reconstruction adopted Lee's paper as reference material.)
} 
Alternatively, the national library could be organized as a functionally integrated system, modelled on that of the British Library, which is managed by a Council. (Lee, P. J. 1980)

Due to the development of information and communications technology, search engines and digitizing technologies, cooperation and coordination proposals have in recent years been discussed more actively than has the argument of joining the two entities.

Lee Jee Yeon criticises the library cooperation network currently progressing at the national level and forming as centred around NLK and public libraries, asserting that a cooperation network at the national level has, in a strict sense, not yet been formed. With the development of digital technology, provision of services has been made possible by linkages in digital use, therefore bringing into existence the need for a support network that connects mutual cooperation services of the three gugga libraries. She states that support for each of the systems is necessary in order for this to be achieved. (Lee, J. Y. 2012)

\section{National Library of Korea and National Assembly Library}

\section{National Library of Korea (NLK)}

The predecessor of NLK is the Library of the Japanese Government-General ${ }^{5}$ of Korea, which was opened in $1925^{6}$. This library was taken over at the end of the Second World War in 1945 and reopened as NLK in October of that same year. In August 1948, the Korean government was formed and in May 1949, NLK formally came into existence. NLK was then affiliated with the Ministry of Education; its organisational structure included the Library Director, a Deputy Librarian and comprised 6 divisions. Classification tables and cataloguing rules designed to meet Korea's actual needs were initiated as were training programs for librarians and other library staff. During that period, the library functioned as a national library, taking on the role of acting as guide and support for other libraries, implementing librarian training through an adjacent librarian academy and

\footnotetext{
${ }^{5}$ At this time, South Korea was under Japanese colonial rule.

${ }^{6}$ NLK $(2006,42)$ reports that NLK was established on November 30, 1923, but referring to NLK 1973 chronology on p. 415, the office was opened on November 30, 1923, while the building was constructed in December 1923 and shown to reporters in January 1924. Premises were fully occupied by April of that same year, although records indicate that the official opening was held in 1925 .
} 
fulfilling many other tasks. It may be ascertained that NLK made a substantial contribution to Korean librarianship.

Due to the outbreak of the Korean War in June of 1950, NLK's structure was scaled down ${ }^{7}$. Based on provisions of the enacted Libraries Act, NLK became the Guglib Central Library in 1963. It was also afforded the function of legal deposit library and national bibliographies publishing library, thus legally becoming a national library.

In November 1974, the Library Director was appointed the level of administrator, the highest executive employee designation level among public officials employed in general service, signifying a significant promotion for the post $^{8}$.

Since 1983, NLK has actively carried out various projects, most important among these being the development of KORMARC (Korean Machine Readable Catalogue), followed by the computerization of library management, the library network and digital library system and online services.

With the Libraries Act revision of 1987, NLK became the ISBN (International Standard Book Number) Registration Agency and in 1988, its main office moved to the newly constructed premises it still occupies today. Reorganisation of the government led to the establishment of the Ministry of Culture in 1990, which also resulted in transferring the affiliation of NLK from the Ministry of Education to the newly established Ministry of Culture. As a result of the organisational and functional adjustments of 2004, the function of formulating library policy was moved from the Library and Museum Division of the Ministry of Culture to the authority of the NLK.

The following libraries have been established subsequent to this period: the National Library for Children \& Youths in 2006, the Korean Research Institute for Library and Information in 2007, the Digital Library in 2009, the National Library for Individuals with Disabilities in 2012 and the National Library of Korea Sejong in 2013.

National bibliographies include: the Weekly List for Legal Deposit Resources, the Korean National Bibliography, the Bibliographic Index of Korea, Korean

\footnotetext{
${ }^{7}$ Office Amendments, May 31, 1957.

${ }^{8}$ Executive Order No. 7297.
} 
MARC (Machine Readable Catalogue) on CD-ROM, the Union Catalogue of Foreign Books in Korea, as well as others.

The duties of NLK include: distribution of the Korean Library Automation System (KOLAS), (a task that has been well assisted by the Korean Library Information System-Network with KOLIS-NET serving as its centre), carrying out domestic cooperative activities and maintaining close relations with libraries nationwide (NLK). NLK is currently home to 3 departments, 3 libraries, 1 research institute, 18 divisions and a team of 275 staff members responsible for approximately 7 million 220 thousand volumes (NLK; KLA 2013).

\section{National Assembly Library (NAL)}

The beginning of NAL reaches back to 1952, when it was set up as a reading room at the National Assembly of the nation's temporary capital, Busan. Reorganisation of the National Assembly Secretariat in 1955 served to enlarge and upgrade the reading room to that of the National Assembly Library. Based on the NAL Act ${ }^{9}$ enacted in 1963, the Library Director may be appointed and dismissed by the Secretary General with the approval of the National Assembly House Steering Committee. The Director is a public official employed in special service ${ }^{10}$. The NAL Act of 1975 set the Director's remuneration package to the level of a ViceMinister employed by the government ${ }^{11}$.

The Act specified that NAL was a deposit library, hence making it obligatory to deliver all materials published by state agencies and public organisations to NAL, while general publications could be delivered upon request.

In the 1960s and 1970s, the library's service and structure grew significantly, which has also served to influence on the upgrade of librarian posts. However, with the military coup of December 1980, the functioning of the National Assembly ceased, the NAL Act was abolished and the library's mechanisms diminished.

\footnotetext{
${ }^{9}$ Act No. 5143, November 26, 1963. Enactment.

${ }^{10}$ Act No. 5143, November 26, 1963. Enactment.

${ }^{11}$ Act No. 2730, December 26, 1974. General revision.
} 
The June Democracy Movement ${ }^{12}$ of 1987 resulted in significant changes within Korean society, among these being direct presidential elections, local autonomous entity system restoration and the protection of political party activities.

As a result, National Assembly activities were also revived. In 1988, the new premises of NAL were completed and the NAL $\mathrm{Act}^{13}$ was re-enacted, allowing NAL to regain its status as an independent organisation of the National Assembly. The post of the Library Director was promoted to that of political service and the organization of the library was also enlarged.

In 1985, a computer office was established, hailing the start of computerized library activities. In the 1997/1998 fiscal year, the "Basic Program for the Digitization of the National Library" was formed, setting the groundwork for providing digitalized services of the library's most important material. The target users' limit was extended from having been over the age of 20 in 1998, to being over the age of 18 in 2005.

NAL publishes the Periodical Index and the National Master and Doctorate Theses Bibliography as national bibliographies. At present, NAL cooperates and collaborates with 1523 institutions for the purpose of sharing and distributing national knowledge and information resources. It currently houses 2 offices, 3 bureaus, 1 library, 18 divisions and 289 staff members responsible for approximately 3 million 150 thousand volumes ${ }^{14}$.

\section{Disputes between the National Library of Korea and the National Assembly Library}

\section{Arguments in Favour of Unification - Guglib Central Library Establishment (1952-1963)}

\section{Dispute Process}

NLK was established upon national independence in 1945, at which point it assumed the position of Library of the Japanese Government-General of Korea. NAL, on the other hand, emerged (in 1952) as a National Assembly Reading Room during the Korean War (1950-1953); it was enlarged and upgraded to the establishment of a library in 1955. Although NLK has a longer history, NAL

\footnotetext{
${ }^{12}$ Also known as the June Democratic Uprising

${ }^{13}$ Act No. 4037, December 29, 1988. Enactment.

${ }^{14}$ KLA 2013 and NAL Accessed July 28, 2014, http://www.nanet.go.kr/english/.
} 
progressed slightly move rapidly during the movement for the enactment of fundamental legislation ${ }^{15}$. The NAL Bill was drafted immediately following the opening of the Reading Room. This draft proposed an organization model similar to those of the American Library of Congress and the Japanese National Diet Library (Kim E. H. 1955, 188), thus granting NAL the role of a national library. Article 4 of the NAL Draft Bill equated the post of its Library Director to the level of a Minister of State and indicated that NAL enjoyed the status of national library. Article 20 defined their relationship as follows: "Current NLK shall become a branch library of the NAL and shall be effectively administered in a way to provide service to the citizens of Seoul in particular" (Kim E. H. 1955, 192; Jo et al. 1956). Although systematically well organized, NAL at the time represented little more than an office/bureau affiliated with the Secretary General of the National Assembly, despite its aspiration to become a national library and not to function merely as a parliamentary library. A bill proposing such changes was on the agenda of the National Assembly in 1956, but did not succeed in stimulating debate and was discontinued.

Conversely, the movement for the enactment of library legislation commenced with the inaugural meeting of the Korean Library Association (hereinafter referred to as KLA). At this plenary session, the necessity of adopting a Library Law gained ground and the subsequent promotion of such legislation resulted in the draft proposal of January 1956. Despite this proposal having been modelled on the Japanese Library Law ${ }^{16}$, it included in its provisions mention of public libraries as well as specific mention of NLK. In May 1957, KLA drafted a Library Law proposal in the form of comprehensive legislation that would include the central library, public libraries, school and academic libraries (including university and college libraries), specialized libraries and KLA (KLA 1957, 6). The proposal was made in November of that same year. It appears this proposal was designed to unify NLK and NAL as a central library. It may be speculated that the reason for the application of a new term, that of a central library, and the non-application of either the names NLK or NAL within the proposal derives from the fact that this

\footnotetext{
${ }^{15}$ KLA $(1977,37)$ includes the entry "Library Law Draft" as one of the items of the December 17 , 1948 Council Meeting. There is no indication of any articles or news related to Library Law following that time. Lee, T. J. (1980) notes: "When the Library Law Enactment Movement was (due to Korean War) seeking refuge in Busan...", but as in the former case, there is no indication of any article or news related to Library Law after that. Although the necessity for the existence of an enacted Library Law is apparent, no materialised proposals were found.

${ }^{16}$ Has the legal name of Library Act, but regulates only the field of public libraries.
} 
period directly followed the National Assembly Library Law proposal that had been rejected by the National Assembly in 1956. It may also have been influenced by the fact that the Head of the Committee ${ }^{17}$ charged with drafting the proposal was affiliated with NAL.

Furthermore, from attestations claiming that "this period marks the beginning of national central library related problems (KLA 1962, 105)" and given that the NAL Law proposal which had been on the agenda of the National Assembly in 1956 had included the question: "Is it possible to enact a law only about NAL in spite of the fact that NLK also exists? (KLA 1962, 125)", it may be concluded that the term central library did not refer exclusively to NLK or to NAL during that period.

The draft that was under consideration of the KLA Council in December 1957 comprised chapters on general provisions, national library, municipal public libraries, private public libraries ${ }^{18}$, school and academic libraries and the Library Association (KLA 1962, 105; 1977, 112-3). Nevertheless, it may be concluded from the Public Library Law draft bill agreed upon in July 1958 (KLA 1977, 114) that up to this point, no general consensus had been reached within the KLA as to the range of libraries that were to be included in the Library Law. Rather, a decision on the range of the Library Law was announced at a later Council Meeting. Since the synthesis received a majority of votes, the proposal (KLA 1958, 52-3) that was afterwards made formally assumed the shape of a comprehensive law. KLA reconstructed the Committee and in November 1958, formulated a proposal that included 4 Chapters and 30 Articles on general provisions, public libraries, school and academic libraries, and the Library Association. Article 3 of Chapter 1 of this proposal is the Guglib Library Act (KLA 1977, 114). This proposal namely includes public libraries and school and academic libraries, but presupposes the enactment of a separate law dealing exclusively with the national library (KLA 1962, 105-25; 1977, 106). It may be presumed that the guglib library in this draft does not refer to NLK, but rather, to the national library. Reasons for this include the fact that both libraries were discussed in the same chapter of the 1957 proposal (the chapter referring to the central library), as well as the fact that during that period, there existed in the Korean general public a fairly low understanding, not only of NLK, but of all libraries in general. The

\footnotetext{
${ }^{17}$ Kim Seong Won.

${ }^{18}$ Established by juristic persons.
} 
possibilities for enactment of a law pertaining exclusively to NLK were likewise non-existent due to its small scale. If this period is to be considered as difficult with respect to library legislation enactment, it is more probable that the guglib library refers to the central library and not to NLK.

In May 1959, a proposal comprising 4 Chapters and 35 Articles on general provisions, public libraries, school and academic libraries, and others, was drafted. Article 4 of Chapter 1 addresses Guglib Central Library. From the contents of this Article, it may be concluded that legislation pertaining to guglib central library was to be regulated separately. Within a period of one year, the term used in the proposal had been changed from "guglib library" to "guglib central library". This circumstance points to an agreement within the library field (with KLA at the forefront) in terms of establishing a national central library. The bill was again introduced in the National Assembly but was again not passed.

As a result of the April Revolution ${ }^{19}$ and the turmoil that led to the 1961 military coup, the year of 1960 was marked by a complete social chaos. The National Assembly was consequently dissolved, while the Supreme Council for National Reconstruction brought legislative, judicial and executive government under its own control, gaining a de facto hold of power.

Immediately following the revolution, KLA proposed the enactment of the Library Law to the Supreme Council, which discussed it and subsequently transferred the jurisdiction of libraries to the Ministry of Education (KLA 1961, 34). On the other hand, the Ministry of Education proposed a separate draft, where the guglib central library became affiliated with the Ministry of Education, while all other libraries were brought under the jurisdiction of guglib central library and Chief of Guglib Central Library was given authority to award designation of the Librarian Certification. KLA protested, arguing that such action was unjust. It approached the Ministry of Education with a proposed revision request and engaged in several meetings with the Ministry of Education and related agencies in regard to the issue (KLA 1977, 121-2). Although the Bill of 1959 determined the enactment of a separate guglib central library regulation, the draft bill of the Ministry of Education affiliated the guglib central library with the Ministry of Education and also appears to have indicated that the draft bill was unjust in terms of the intent to regulate libraries.

\footnotetext{
${ }^{19}$ Students demonstrated against the autocratic leader Rhee.
} 
Facing powerful opposition from the library field, the Ministry of Education formulated a new draft bill comprising 4 Chapters and 23 Articles in 1962. This draft bill constituted general provisions, public libraries, school and academic libraries and penal provisions, and included within its structure: Chapter 2 - Public Library: First Paragraph - General Provisions, Second Paragraph - Guglib Central Library, Third Paragraph - Municipal Libraries, Fourth Paragraph - Private Public Libraries. Unlike previous proposals, guglib central library was considered as a part of the chapter on public libraries and hence, its status diminished.

While the Library Law draft bill was being discussed at the Vice Minister's meeting, KLA organised the first Korean Library Conference. The topic of the conference was "Year of Library Law Enactment" and there were public discussions on "issues related to the guglib central library establishment". Since the Library Law draft bill included provisions on guglib central library, circumstances surrounding the form of its establishment depended on the enactment of legislation that would mark the passing of this draft. With the intent of holding a public "debate on the possibilities for establishing a guglib central library with expenditure currently engulfed by both NAL ${ }^{20}$ and NLK (KLA 1962, 114)", representatives of a public library, a university library, NLK, NAL, and a special library each expressed their opinion regarding the role and function of the guglib central library. Four of five representatives supported the establishment of an improved guglib central library as opposed to the unification of NLK and NAL.

Immediately following this conference, the draft bill being discussed at the Vice Minister's meeting was withdrawn ${ }^{21}$. Reasons for this withdrawal stemmed not only from issues directly related with the guglib central library. In a period during which the number one item determined by national policy was economic development ${ }^{22}$, it may reasonably be assumed that the reasons for the withdrawal were grounded in the draft bill having placed too great a burden on obligatory library establishment regulation and professional librarians' placement regulation-both of which were directly connected with the national budget (KLA 1963, 15).

It is nevertheless true that this period had been timely for the resolution of issues related to the establishment of guglib central library. For a substantial period of time, the role of guglib central library had been under public scrutiny and

\footnotetext{
${ }^{20}$ At the time called Supreme Council for National Reconstruction Library.

${ }^{21}$ The $48^{\text {th }}$ Vice Ministers meeting minutes, July 26, 1962.

${ }^{22}$ Five-Year Economic Development Plan. First implemented in 1962, a government-led five-year economic development plan that resulted in rapid economic growth.
} 
the Library Law proposal was withdrawn after the support for its enactment had already been broadly determined. During the course of this research, the author has, however, been unable to identify a movement which encouraged the establishment of guglib central library on the part of NLK, NAL, their overarching institutions (Assembly Secretariat and the Ministry of Education) or even by KLA. In July 1963, the Ministry of Education proposed a draft bill that consisted of 4 Chapters and 29 Articles and which amended only the condition of the large budgetary burden. This finally resulted in the acceptance of the bill by the Supreme Council for National Reconstruction in October of that same year.

\section{Discussion}

Those who argued in favour of establishing a guglib central library on the basis of unifying the two libraries did so with the desire that the libraries fulfil their function as a national central library. Because the functions, services and activities of both libraries overlapped, it was impossible to avoid a waste of public funds. Most of those in favour of the libraries' unification aspired for the establishment of a guglib central library that centred on NAL. For this reason, an extensive research pertaining to the establishment of a guglib central library centred on NAL was carried out, including a Guglib Central Library Act proposal (Kim, E. H. 1955; Lee, C. K. 1962).

The reason for the fact that much of the public opinion was in favour of a NAL centred guglib central library was based on the argument that NLK did not have sufficient prerequisites to fulfil the guglib central library function. These arguments may be synthesized with the following points: 1. Affiliation of NLK with the Ministry of Education - a government agency did not make this library different from others established by governmental agencies. 2. NLK received poor treatment within the Ministry of Education and the impression of employees having been demoted was fairly strong. 3. Due to frequent changes surrounding the post of Library Director, it seemed improbable that a lasting, consistent library policy be formulated. 4. Given that, status wise, the position of the Library Director meant little more than a position of Chief of a Bureau, many disadvantages were apparent regarding library management. 5. The Ministry of Education faced numerous problems regarding the need for an urgent resolution of 
issues related to the improvement of school facilities ${ }^{23}$, thus it was also unable to financially or even spiritually assist the nourishment of libraries. 6. A cooperative system of assistance organization fostering the library function had not been organized within the Ministry of Education.

By comparison, NAL was: 1. Affiliated with the National Assembly, an institution overlooking budget related proceedings and thus able to more liberally dispose with the budget as compared to a bureau of the Ministry of Education. 2. Distanced from political influence. 3. As an independent agency of the National Assembly, NAL had the authority to manage library personnel affairs as well as the possibility to secure the most exceptional talents. 4. Its Library Director post enjoyed high status, which was advantageous for domestic as well as foreign library cooperation. 5. The United States of America (representing Korea's closest ally) and Japan (being closest to Korea's sentiment) successfully managed their legislative authority libraries (the Congress and Diet) as their respective National Libraries.

The reasons for opposing the establishment of a national central library centred on NAL were as follows: 1. Although the National Libraries of the United States and Japan are legislative authority libraries, there are internationally more examples of national libraries affiliated with branches of executive government. 2 . NAL's primary objective was to support the legislative activities of members of the National Assembly, therefore making NAL unsuitable for taking on the role of a national library.

\section{Overview}

Although the library field has reached mutual consensus with respect to the benefit that would arise from establishing a national central library, such a library has not yet been established. The period during which active debates and bill proposals took place was politically chaotic, which effectively resulted in the failure to pass library legislation.

Furthermore, debate over the establishment of the national central library centred on the economization of national resources. Namely, since the affairs of both libraries overlapped, the national library that was to be founded also needed

\footnotetext{
${ }^{23}$ Compulsory education had been introduced, but the government faced the problem of having insufficient facilities. Government-owned public companies subsequently developed schools through the "School Facilities and Equipment Improvement Plan" and other similar initiatives.
} 
to be economically viable. At that point in time, there prevailed arguments in favour of integration that was to be centred on NAL primarily because NAL enjoyed comparatively better conditions than did its counterpart. Disregard towards NLK as being a viable option likewise resulted in greater attention being afforded to NAL.

It must finally be noted that the library field devoted substantial efforts to the enactment of library legislation. Having engaged in a "too hasty" approach may also be considered as reason for the consequential results. Librarians of the time were of the opinion that the formation of library legislation was decisive for library development. KLA had been struggling for the enactment of library legislation since its very foundation. Although the National Assembly had been silenced during the military coup of 1961, the library field proposed a draft bill which led to enactment through a formulation guided by the Ministry of Education. However, the Ministry of Education did not, at that time, have sufficient understanding for libraries and therefore passed the bill with conformance to the governmental policy, while continuing to disregard the wishes of the library field itself.

The desired result of library legislation enactment had been obtained, but the result consequently had large and adverse effects on the lack of establishment of a national central library. For that reason, the guglib central library became a library affiliated with the Ministry of Education and was given a mention in the chapter on public libraries, which served to create its image as being central among public libraries and not the national library itself.

\section{Unification Discussion - Gugga Central Library Establishment (1964- 1987)}

\section{Dispute Process}

Even after the Libraries Act had been enacted and the guglib central library founded, debate on the unification of NLK and NAL remained vibrant. This was influenced by both internal and external factors.

1. That previous discussions regarding guglib central library had not yet reached a conclusion was one internal factor. Immediately following the enactment of the Libraries Act, NLK was renamed guglib Central Library (of Korea). The term guglib central library, as applied by the library field, was not 
simply a designation for one organisation, but instead served as a designation for a central library of the State, essentially comprising the integration of NLK and NAL. However, following a passage of the Libraries Act, the designation of NLK was changed to "guglib central library", in accordance with what had been determined by the Act. This served to create a gap between the resulting reality and the guglib central library that had initially been envisioned in the original law enactment process. As a result, the terms gugga central library and gugga representative library emerged in place of guglib central library. 2. Since NLK was affiliated with the Ministry of Education and was regulated on the basis of the chapter on public libraries, its image as that of a library affiliated with an office of the Ministry of Education and as a central library among public libraries was stronger than the image of being a central library of the state. 3 . Relocation due to material increase also resulted in the prevalence of unification support and may be identified as the final internal factor.

External factors were based on the United Kingdom's research of the functions, organisations, services and other characteristics of national libraries that had resulted in a unified structure-scheme proposal in Britain (International Encyclopedia of Information and Library Science 2014, 48). As a result of this research, The British Library Act was enacted in 1972, and served to unify several libraries with long history and tradition into The British Library in 1974. This also served as the most prominent argument among supporters who were in favour of unifying national libraries in Korea (Grogan 1973; Jang 1974, 1975; Lee B.S. 1974; Ha 1974; Han, S.J. 1978).

Until the mid-1970s, analyses carried out with respect to the functioning of the National Diet Library in Japan, the Library of Congress of the United States and the National Library of Australia indicated that these libraries managed their facilities and services in a rational and effective manner. These conclusions had a strong influence on the library field, leading the majority to express preference for a unified central library management system in Korea, as opposed to having several separate libraries with similar functions (Jang 1964, 1974; Lee, C. K. 1965; Yun 1966; Lee, B. S. 1974; Eom 1974; Kim D. H. 1974; Ha 1974).

KLA also prompted the Ministry of Education and related agencies to prepare an annual library promotion plan for the country and proposed the union of both libraries as one of the necessary conditions to be included in the plan, hence 
officially expressing in favour of unification. Its explanation of reasons mandating unification read as follows:

In order to facilitate the enlargement of national scope of operations, both libraries shall be merged, their personnel, funds, collections and other shall intensively be brought together. Creation of a national bibliographic control, union catalogue, creation and distribution of printed catalogue cards, production and storage of microfilm of valuable materials and others. (KLA 1967, 3)

The discussion surrounding the relocation of both NLK and NAL around 1974 coincided with the most active debate of the libraries' unification up until that time. 1974 also marked the $100^{\text {th }}$ anniversary number of NAL's bulletin, which included in its publication statements of librarians prompting the unification of both libraries for the purpose of developing the country and the library system.

The prevailing voice of support reasoned that because it was difficult for either library to manifest the national library role, it was necessary for them to unify and therefore, fulfil the modern library function based on a model of NAL centred unification. (Lee, B. S. 1980; Kim, D. H. 1974; Eom 1960; Jang 1974)

The reason as to why it was impossible to unify around NLK lay in the fact that NLK was little more than a government office library and not a national library. Popular opinion also believed that the low positioning of the post of its Library Director would serve to hinder the library's activities both at home and abroad. (Jang 1974, 45)

Those who opposed NAL-centred unification did so with the argument that NAL's primary service was to the National Assembly. Thus NAL could not become a national library, but could only remain a specialized, parliamentary library. (Lee, S. J. 1974, 48)

As the opposition to unification and the establishment of one powerful national library grew, support for a different perspective-that of the libraries' coexistence - also emerged. This perspective argued that the national libraries could share the role of national library (Kim, J. H. 1969; Kim, S. I. 1974; Jeong 1978). In addition, there also rose viewpoints which opposed unification in a more indirect manner, stating that NLK's current position as a gugga central library had already been legally recognised and was therefore undisputable (Lee, C. S. 1969; Lee, S. J. 1970). 
In 1975, NLK drafted three Library Law revision proposals. Article 17 (Establishment) of the first proposal stipulated that:

The provision of library services determined by this law shall be made by NLK, placed in affiliation to the minister in charge of education, an institution representing the state in domestic and foreign library activities. (NLK 1975)

Article 12 (Establishment) of the second proposal noted:

In NLK, the state shall place the central library mechanism for the collection of books and other related library material and provision of library services under this law to each legislative, judicial, administrative institution and the citizens. (NLK 1975)

Finally, Article 18 (Positioning) of the third proposal specified that:

NLK shall be a representative library at home and abroad. (NLK 1975)

The first and the third bill emphasize the role of NLK as the state representative library, while the second bill places importance on the central library and considers the possibility of unification with NAL. Although not visible on the surface, NLK did not exclude the possibility of unification. Its proposals may therefore be viewed as attempts to put forward a library representing the state and to achieve prominence through unification.

During the economic development of the mid-1970s, public opinion began to shift towards opposing unification. This was primarily due to the growth of NLK, the reorganisation of its management structure, its research duties as a national library and the broadening of its services.

This same trend of opinion is also apparent in KLA's Korean Library Development Plan of 1979 (KLA 1979). In this plan, KLA examined the situation of public libraries, university libraries, school libraries, special libraries and librarian training. Although it had drawn up the plan for the purpose of library development, it afforded no mention of a national library. Debate surrounding implementation of the plan began in 1975. Since opinions on the plan's periods of goal setting and process of development differed, a special committee was formed in 1977 with the purpose of planning its development process. Although it was stated that the plan was relevant for library law revision proposals, there was no mention of a national library. The library law that was being debated at that time was an example of comprehensive legislation that covered all libraries; the 
development plan also included all types of libraries. By comparison, the proposal created by KLA in 1967 had demanded unification of both libraries. The exclusion of a national library from the formulation of a national library development plan is therefore quite unusual. Opposition against unification continued to grow stronger and on the basis of available documentation, it may be presumed that common ground on the unification issue had not been reached even within KLA itself.

In the midst of this situation, there occurred the military coup of 1979, bringing about the reorganisation of the National Assembly in 1980. NAL's affiliation was transferred to the National Assembly Secretariat, causing it to lose its independent status. The National Assembly Library Act was abolished and the movement for NAL-centred unification lost influence. Furthermore, in 1984, the House Steering Committee published a plan to reform the National Assembly Secretariat and NAL. The contents of the portion of the plan referring to the library provide that:

In America and Japan, the parliament library performs the national library functions, but in our country NLK has been established. NAL should be distanced from the role of the national library and make the most of its specialisation as a genuine parliament library. Even if it shall be cultivated as a special library focusing on social sciences, such as politics, parliament, economy and others, it has many characteristics as a public library. (National Assembly 1984)

After this report served to finally bring an end to the proposal of NAL-centred unification that was being led by those affiliated with NAL, the library's prompts for unification ceased.

As a result, the amended Libraries $\mathrm{Act}^{24}$ of 1987 consisted of 8 Chapters and 47 Articles. Chapter 2 dealt exclusively with NLK and included the following provision: "In order to operate effectively, NLK will cooperate with NAL." This may be viewed as a complete acknowledgement of the capabilities of NAL, that is, an acknowledgment of NAL as a national library similar to that of NLK. It may also be viewed as an effort to resolve conflicts with NAL in a positive manner.

\section{Debate}

During this period, rivalry may be observed between NAL (which had a substantially superior budget, staff resources and functional capacity) and NLK

\footnotetext{
${ }^{24}$ Act No. 3972, November 22, 1987. Amendment.
} 
(which legally held the position of a national library). NLK was now in the situation of maintaining its legal status and did not actively participate in the unification debate. Conversely, up to the mid-1970s, NAL had still occasionally insisted on unification. Prior to the enactment of library legislation, active debate on the establishment of a national central library continued to take place. The debate focused primarily on NAL-centred unification, but also gave rise to negative views and the emergence of a conservative theory on the issue of unification.

In summary of its argument, the unification theory proposes the establishment of a library as an independent state organisation not belonging to any administrative agency in order to effectively be able to respond to budgetary and staff resource demands, facilities, collection development, international material exchange and similar matters, since a national library such as this does not currently exist. (Jang 1964, 1974; Lee, C. K. 1965; Yun 1966, 1969, 1975; Kim, J. G. 1969; Lee, C. H. 1974; Kim, S. I. 1974; Jang 1974; Kim, D. H. 1974; Ha 1974; Eom 1974; Lee, B. S. 1974, 1980; Lee, P. J. 1980)

Those insisting on NAL-centred unification proposed a politically unbiased national library, one that would not be affiliated with ministries or government offices. At the same time, it was also argued that affiliation with the National Assembly would be more beneficial from a politically unbiased point of view when taking into account the position of its Library Director. The positive budgetary aspect of an agency that was under the direct supervision of the National Assembly rather than the Ministry of Education was also provided as an advantage favouring NAL-centred unification (Jang 1964; Lee, C. K. 1965; Yun 1966, 1969; Kim J. G. 1969; Kim, D. H. 1974; Ha 1974; Eom 1974; Lee, B. S. 1974, 1980; Lee, P. J. 1980). In reality, NAL's budget was growing while that of NLK was decreasing. This was coupled with a remarkable rise in the number of books available on NAL's shelves.

Supporters of the conservative theory (Kim, S. I. 1974; Jang 1974) proposed the formation of a special board for the purpose of unification and for grounding unification in research that would lead to the examination of a comprehensive and specific unification plan for the purpose of establishing a single national library in its name and substance. Though this board was never actually formed, the idea itself represented an advanced approach that would serve to avoid prejudiced disputes which resulted from the unification issue being treated solely from the 
librarian point of view. The idea was that the board would evolve the issue using a more comprehensive, substantiated and influential mechanism.

In summary, opponents of unification were unable to provide evidence that it would be right for Korea to follow the example of the United States, Japan and a few other model countries, whose parliamentary libraries served the function of National Library. They were of the opinion that NAL should become the national library, particularly given that its budgetary and personnel conditions (including the status of its Library Director), were superior to those of NLK. Yet realistically, the possibilities for unification were low. If both libraries were to divide service divisions among themselves, the possibility for a special research library, where each of the two libraries would be able to most effectively develop their respective roles, would be more feasible. (Jeong 1978; Kim, Jung Han 1969; Lee, S. J. 1974; Kim, S. I. 1974; Yun, Y. D. 1978; Kim, Jong Ho 1978)

The libraries did actually communicate with one another on the issue of unification. A record from April 1974 (NAL 2012, 517) confirms that representatives of both libraries were present at a round table conference while the unification debate was gaining ground. Since it appears that neither of the parties were able to convey their views, the meeting did not bring about any fruitful results. This demonstrates significant differences in the views of each of the libraries, as has also been evidenced by the points explained above.

\section{Overview}

During the Five-Year Economic Development Plan that began under government guidance in 1963, NLK faced successive budgetary cuts; its rate of growth was also inferior to that of NAL. In the midst of this period, there also emerged an order that NLK be changed to gugga central library, a state agency in name and substance. But the NLK's primary mission was to fulfil its role as a public library, while it also served the special function of carrying out the tasks and duties of the central library (NLK 1966). When viewed from this perspective, the low recognition for the idea of a national library makes sense. However, the military coup of 1979 brought about the weakening of the National Assembly in 1980, causing NAL to lose its position as an independent agency as well as its power to discuss unification.

Furthermore, discussion on the unification issue taking place at this time had limited conditions: there were circumstantial differences of both libraries; 
examining the case of The British Library served to bolster support in favour of unification; however, Korea's was a different example of affiliation with the National Assembly and the public administration. On the surface, these seemed like unification attempts by two libraries that sought to develop a better functioning national library. Possible adverse impacts of unification remained under-researched, while a real and long lasting plan for unification was not created. The debate may ultimately be defined as a futile discussion without any substantial movement.

\section{Qualification Discussion—Gugga Representative Library (1987- present)}

\section{Dispute Process}

Keeping pace with national economic growth, both libraries experienced continual expansion. In 1988, both libraries relocated to newly built premises. The new government that came into power that same year announced that a new Ministry of Culture was to be built. Librarians issued public statements and organised round tables, thus actively promoting relocation of the Ministry of Culture. Despite resistance from the Ministry of Education (which held vested interest on the issue), the relocation of the Ministry of Culture was decided in 1990.

The Ministry of Culture drafted the Public Library Act (draft bill) in 1990. Article 17 (Duties) of the Proposal stipulated that: "NLK shall perform the duties in the following Subparagraphs". Subparagraphs 1 to 11 list NLK's obligations, while the final Subparagraph, Subparagraph 12, specifies: "Other services necessary for executing the function as the representative library of the State". (Ministry of Culture 1980) This represented recognition of the discussions that had taken place up to that point, and most likely gave an expression to a state representative function held by NLK. This proposal was enacted as the Library Promotion $\mathrm{Act}^{25}$ in 1991. The second chapter of this Act was dedicated to NLK, in Article 16 (Duties) Clause 1, stipulating: "The National Central Library, as the representative library of the State, shall carry out the following service", subsequently listing 11 items. Namely, the title guglib central library does not give the impression of representing the (interior and exterior of the) State, therefore this recognition was explicitly stipulated in the law, since the recognition of a sole library representing the (interior and exterior of the) State was low. In the proposal,

${ }^{25}$ Act No. 4362, March 8, 1991. Enactment. 
the role of gugga representative library was one of the duties afforded to NLK, whereas law-associated tasks were identified as not being the duties of the national central library, but rather, the duties of the library representing the State. Specifically, qualifications of a national representative library were afforded to NLK and the library was expected to fulfil the role of the central library within their context.

Social changes in the second part of the 1990s also influenced library institutions and resulted in a renewed urge for the revision of library legislation. In 2003, the Institution for Culture and Tourism Policy (affiliated with the Ministry of Culture) conducted research on the Library Law, which resulted in the publication of a tentative revision. In the third chapter of its proposal, the term gugga representative library was used instead of guglib central library. This brought up the necessity for materialisation and clarification of the role of a library representing the State. Clarification of its role and function was made under the chapter title: Gugga Representative Library (Kim, S. H. 2005, 11). Yet, in comparison with other chapters on public library, university library, school library and others, this chapter was somewhat imbalanced. To better balance it with other chapters, application of the term gugga library was deemed more appropriate (Hong 2004, 41). As its existence had now been legally acknowledged, Gugga Representative Library was arranged into a separate chapter, and from 1991 onwards, national representative library as a designation came into use. On the other hand, this term was also applied to NAL (Lee, M. H. and Lee, S. L. 2002; NAL 2005), resulting in continued dispute between NLK and NAL as to which of the two carried the position of the representative library of the state (Kim et al. 2003, 109). Inserting the Gugga Representative Library chapter into the Library Law indicates the intent to appoint NLK as the sole gugga representative library of the State.

Gugga representative library is another expression for a national (central) library, but criticism has been voiced due to the specific interpretation of the term and the difference in function not having been made sufficiently clear. Due to the criticism afforded to the use of gugga representative library, Guglib Central Library was reused as the third chapter title, yet since a clear conclusion on the use of terminology has never been reached, it remains unclear as to what the correct 
role of gugga representative library actually is. Article 18 (Establishment, etc.) of the Libraries $\mathrm{Act}^{26}$ from 2006 stipulates:

(1) The Minister of Culture and Tourism shall set up the National Library of Korea under his/her control as a library representing the State.

(2) Where it is necessary for the efficient business handling and balanced development of district libraries, the National Library of Korea may establish branch libraries according to district and field as a library representing the State.

Further Article 19 (Duties) stipulates:

(1) The National Library of Korea shall perform the duties in the following Subparagraphs.

Library duties are listed in Subparagraphs 1 to 7 of Article 19. Subparagraph 8 determines: “.. other services necessary for executing the function as the representing library of the State".

Namely, NLK is stipulated as being the representative library of the State, yet the duties and established purpose of the vital central library of the State remain unregulated. It follows that the establishment of branch libraries by field and by region is not the obligation of NLK as central library of the State, but has been included within the description of Disposal of Business Affairs, a task of the gugga representative library. Rather than this being a role of the central library of the State and representing the preservation of its representative position in Korea, Articles 18 and 19 must be understood as products of an error that was made when setting the focus.

Another item causing discord between NLK and NAL resulting from the 2003 proposal is the provision on cooperation. Subsequent to the Law of 1987, the following provision was included with respect to NLK duties: "NLK shall cooperate with the NAL in order to efficiently execute its duties". Opinion is divided as to why this provision was not included in the proposal of 2003. On the one hand, the omission has been viewed as serving to effectively cease cooperation with NAL as a result of NLK not having the intent to cooperate with NAL, resulting in the further assumption that cooperation had not been positive (Hong 2004, 41). On the other hand, NLK cooperation with other libraries was seen as something natural, therefore it follows that there was no necessity to specifically mention any cooperation with NAL (Oh 1988, 12). If NAL was to be

\footnotetext{
${ }^{26}$ Act No. 8069, December 20, 2006. Amendment.
} 
treated as a library performing the gugga library function, this should be considered as mutual cooperation. This stipulation has legitimacy, but loses legitimacy if NAL is perceived as merely a guglib library. NAL is not the only guglib library. Other guglib libraries include the Supreme Court Library of Korea, National University Libraries and, if libraries established by each Ministry were treated in a strict fashion, these would also all be guglib libraries. It is therefore unjust to perceive NAL simply as a guglib library.

\section{Debate}

After 1987, theories surrounding the unification of both libraries disappeared, but the disputes between NLK and NAL remained. In the governmental organisation of 1988, library policy was transferred to the Ministry of Culture, while the Library Act of 1991 granted NLK the qualifications of a library representing the State, laying down the operations of gugga representative library. Although various terms defining the role and position of NLK as a national library had been applied in the past, the meaning and position of its status continued to lack clear definition. The designation gugga representative library represented an addition to its qualifications. For this reason, even its operation as a national library in accordance with regulations does not clearly establish its general affairs as a gugga representative library. It may be said that this has been the root of the negative effects which have subsequently resulted from its disputes with NAL. Both NLK and NAL must cease viewing the other as a competitor; they must stop engaging in a competitive approach with one another. Even if NAL is not deemed to be a national central library, it is one of the national libraries and has (historically) been functioning as such (Han 2002, 101, 147). That NLK is a national library should be discussed after its being a central library is acknowledged.

\section{Overview}

Immediately after the library administration was moved to the supervision of the Ministry of Culture in 1991, no objection was raised when enactment of the Library Promotion Act qualified NLK as a library representing the State. In addition, following the transfer of affiliation to the Ministry of Culture, only one article prompting unification was published.

After NLK's affiliation was transferred to the Ministry of Culture, the services provided by NLK have continuously expanded. Stated differently, NLK has 
experienced significant growth as a result of the attention the Ministry has vested into library matters. Austerity was emphasised during the IMF bailout of 1998, when a sweeping reform of national level organisations was deemed necessary. There appeared a movement encouraging that NLK management be contracted, and despite NAL also facing contraction of its own structure, there were mp appeals to unify both libraries. This can be viewed as an acknowledgment of the existential value of both libraries, of seeing the unique function of each as separate entities - those of NLK and NAL.

Nevertheless, disputes surrounding the title, role and position of gugga representative library have not been dissolved. NAL has been striving to effectively carry out its role as a gugga representative library (Jo 2005; NAL 2005), therefore it is invalid to treat NLK as the sole gugga representative library. Consequentially, gugga representative library should not be treated as a mere designation, but needs instead to be acknowledged as clearly fulfilling its unique role and function.

\section{Conclusion}

NLK was the first of the libraries to be established, but during its initial period, it did not actually serve as a library, given that the Korean War broke out just after the conclusion of the Second World War. It was at this time that NAL was founded. Over subsequent years, NAL consistently grew. In the 1950s, Korea was one of the poorest countries in the world. As a result, the budgets of both libraries were extremely limited and were thus incapable of retaining a sufficient number of experts. Therefore, the debate on unifying both libraries into a single national library must be understood as completely reasonable and natural.

However, supporters of NAL-centered unification were very active at the beginning of the library unification debate. They used a unilateral approach that was influenced primarily by their perceptions of the national libaries of the Unites States of America and Japan, presenting these as being the most desirable model(s) to be applied in Korea.

At the same time, there was little understanding of the pro-unification environment that surrounded both libraries. A thorough analysis of the material and intangible capacities of both libraries for the purpose of unification was not conducted. The same can be said for a phased plan that would gradually bring forth a rational and practical unification process. Due to the coexistence of the two 
libraries (both managed through state support), a long-standing rivalry existed between them and numerous disputes occurred in the process of recognizing the other's role.

With the development of IT, library material has been digitazed. As networks have been formed, the debate arguing for physical unification has ceased. The current debate deals with the national library cooperation system and system construction. In March 2012, a seminar on the joint policy of three gugga libraries (NLK, NAL and the Supreme Court Library of Korea) entitled "Mutual Cooperation among National Libraries for the $21^{\text {st }}$ Century Knowledge Information State" was held (Lee, B. S. et. al. 2012). This seminar served as an opportunity for promoting cooperation among and between members of the National Assembly and the three gugga libraries, a cooperation that would be implemented through the participation of library science researchers and library representatives. Rather than placing a focus on the unification of services, the seminar facilitated discussion on realistic coordination and cooperation programmes. It presented the direction for both libraries to take from then onwards. It is expected that specific proposals on coordination and cooperation shall be discussed in future.

It is believed that the organisation of such seminars and on-going public debate serve as a welcome opportunity for an examination on how to dissolve long-standing disputes between the two libraries and enable them to more effectively accomplish their mutual role of a National Library. Nonetheless, the debate should not cease with the coordination and cooperation between the two entities, and should not limit itself on how to best ensure the role of national library. Instead, it is also necessary to continue with the debate on the National Library System as a whole - one that includes coordination and cooperation among all libraries. To prevent the reoccurrence of past disputes, it is primarily necessary that the libraries conduct a thorough self-analysis; an objective thirdparty evaluation and research must to be undertaken as well. Following this, it would be preferable to create a system enabling coordination and cooperation among all libraries as a collective part of Korea's national library system. 


\section{References}

Dictionary.com. Dictionary.com Unabridged. Random House, Inc. Accessed July 27, 2014. http://dictionary.reference.com/browse/national library.

Eom Dae Seob 엄대섭. 1960. "Hanguk doseogwan baljeoneul wihan gukga jeongchak 한국도서관발전을 위한 국가정책 (National Policy for Library Development in Korea)." KLA Bulletin 도서관문화 1(3): 21-26.

—. 1974. "Hanguk Doseogwangyeui dangmyeon gwajewa gukga daepyo doseogwanui seolchi 한국도서관계의 당면 과제와 국가대표도서관의 설치 (Issues in the Korean Library Field and the Establishment of National Representative Library).” National Assembly Library Review 국회도서관보 100: 39-41.

Feather, John, and Sturges, Rodney Paul, eds. 2003. International Encyclopedia of Information and Library Science. London and New York: Routledge.

Grogan, Denis J., translated by Ryu, Gyeong Hee 1973. "Yeonggukeui gukga doseogwan jedo 영국의 국가도서관 제도 (National Library System in Britain)." Jeongbo gwanri yeongu 정보관리연구 6(6): 164-66, 155.

Ha Dae Saeng 하대생. 1974. "Gukhoe doseogwangwa guklib doseogwaneun josokhi tonghap doeoya handa 국회도서관과 국립중앙도서관은 조속히 통합되어야 한다 (National Assembly Library and National Library of Korea Must Integrate)." National Assembly Library Review 국회도서관보 11 (6): 53-59.

Han Sang Wan 한상완. 2002. "Gukhwoe doseogwanui gukga doseogwan euroseoui baljeon banghyang. Iship il segi gukhwoe doseogwan baljeon jeonlyak 국회도서관의 국가도서관으로서의 발전방향. 21세기 국회도서관 발전전략 (National Assembly Library Development into National Library. Development Strategy of the National Assembly Library in the $21^{\text {st }}$ Century)." Seminar on the Occasion of the $50^{\text {th }}$ Anniversary of the National Assembly Library 국회도서관 개관 50주년 기념 학술세미나. Organizer: National Assembly Library. Location: National Assembly Member's Office Building. February 20.

Han Sun Jeong 한순정. 1978. "Yeonggukeui Doseogwan Jeongchaek 영국의 도서관 정책 (British Library Policy)." National Assembly Library Review 국회도서관보 15(5): 17-24.

Hong Wan Sik 홍환식. 2004. "Munhwa gwangwangbuui doseogwanbeop gaejeong sianui munje 문화관광부의 도서관법 개정 시안의 문제 (Issues of the Revised Draft Bill of the Library Act by the Ministry of Culture and Tourism)." National Assembly Library Review 국회도서관보 41(8): 40-43.

Humphreys, K.W. 1996. "National Library Functions." UNESCO Bulletin for Libraries. 20(4): $158-169$.

IFLA (The International Federation of Library Associations and Institutions) 2014. National Libraries Section. Accessed July 27, 2014. http://www.ifla.org/about-thenational-libraries-section. 
Jang Il-Se 장일세. 1964. "Doseogwan beopgwa gukhoe doseogwan beop 도서관법과 국회도서관법 (Libraries Act and National Assembly Library Act).” National Assembly Library Review 국회도서관보 1(6): 107-13.

—. 1974. "Urinara doseogwan baljeoneul wihan jeeon 우리나라 도서관 발전을 위한 제언 (A Proposal for Library Development in Korea).” National Assembly Library Review 국회도서관보 100: 42-48.

—. 1975. "Gukga jungang doseogwan seolchireul wihan gochal 국가중앙도서관 설치를 위한 고찰 (A Study of Establishment of the National Central Library)." National Assembly Library Review 국회도서관보 107: 9-17.

Jeong Pil-Mo 정필모. 1978. "Seonjin hangugeul wihan doseogwan jeongchaek 선진한국을 위한 도서관 정책 (Library Policy for a Developed Korea)." KLA Bulletin 도서관문화 19(8): 4-6.

Jo Jeong Gwon 조정 권. 2006. "Doseogwan beop gaejeong(an)e gwanhan sogo 도서관법 개정(안)에 관한 소고 (A Study of Library Act Draft Bill Amendment)." National Assembly Library Review 국회도서관보 42(5): 45-49.

Jo Sun et al. 조순외 15인. 1956. Guglib gughoi doseogwan beoban 국립국회도서관법안 (National Assembly Library Act Bill). Bill No. 030152. February 10, 1956.

Kim Doo-Hong 김두홍. 1974. "Gukhoe doseogwangwa guklib doseogwanui tonghabeul chokguham 국회도서관과 국립중앙도서관의 통합을 촉구함 (Appeal for Integration of National Assembly Library and National Library of Korea)." National Assembly Library Review 100: 42-48.

Kim Eung Hyeon 김응현. 1955. "Gughoe doseogwanui gwageo hyeonjae mirae 국회도서관의 과거 현재 미래 (Past, Present and Future of the National Assembly Library)." National Assembly Review 국회보 2(1): 182-93.

Kim Jong Go 김종고. 1969. "Urinara doseogwanui baljeonchaek 우리나라 도서관의 발전책 (Development Policy for Korean Libraries).” National Assembly Library Review 국회도서관보 6(20): 5-50.

Kim Jong Ho 김종호. 1978. "Doseogwan baljeonui jeongireul maryeonhaneun haero 도서관 발전의 전기를 마련하는 해로 (This Year Will Be Transitional for Library Development)." KLA Bulletin 도서관문화 9(1): 2.

Kim Jung Han 김중한. 1969. "Hangugui doseogwan baljeon gyehoek 한국의 도서관 발전 계획 (The Plan for Library Development in Korea)." KLA Bulletin 도서관문화 10(9): 10-17; 11(1): 12-26.

Kim Se Hun et. al. 김세훈 등저. 2003. Doseogwan mit dokseo jinheung beop gaejeong an yeongu 도서관 및 독서 진흥법 개정안 연구 (A Study of Library and Reading Promotion Act Amendment). Seoul: Korean Culture and Tourism Institute. 
Kim Se Hun 김세훈. 2005. Doseogwan mit dokseo jinheung beob gaejeongeul wihan gongcheonghoe jaryo 도서관 및 독서 진흥법 개정을 위한 공청회 자료 (Public Hearing on Library and Reading Promotion Act Amendment). Organizer: Culture and Tourism Committee, National Assembly.

Kim Se Ik. 1974. "Gughoe doseogwane baranda 국회도서관에 바란다 (Expectations from the National Assembly Library)." National Assembly Library Review 국회도서관보 100: 27-30.

KLA (Korean Library Association). Accessed July 28, 2014. http://www.kla.kr/jsp/main.do.

—. 1957. "Sosik 소식 (News).” KLA Bulletin 도서관문화 3: 6.

—. 1958. "Hoiuirok 회의록 (Meeting Minutes)." KLA Bulletin 도서관문화 7: 49-55.

—. 1961. "Hoiuirok 회의록 (Meeting Minutes)." KLA Bulletin 도서관문화 2(4): 30-34.

—. 1962. "Gonggae Toui: Doseogwan beopgwa hanguk doseogwanui jillo 공개토의:도서관법과 한국도서관의 진로 (Open Discussion: Libraries Act and the Future of Korean Libraries)." KLA Bulletin 도서 관문화 3(4): 105-25.

—. 1963. "Doseogwanbeop jwadamhoe hoeuirok 도서관법 좌담회 회의록 (Records of the Library Act Discussion Session)." KLA Bulletin 도서관문화 4(7): 12-27.

—. 1977. History of Korean Library Association for Thirty Years 1945-1974 한국도서관협회 30년사 1945-1974. Seoul: KLA.

—. 1979. "Hanguk doseogwan baljeon gyehoek 한국도서관발전계획 (The Plan for Library Development in Korea).” KLA Bulletin 도서 관문 화 20(7): 2-30, (8): 15-30.

—. 2013. Korea Library Yearbook 2013 한국도서관연감 2013. Seoul: KLA.

Lee Bong Sun 이봉순. 1974. "Gukhoe doseogwane baranda 국회도서관에 바란다 (Expectations for the National Assembly Library).” National Assembly Library Review 국회도서관보 100: 20-22, 24.

—. 1980. Hangugui doseogwan baljeoneul wihan gukga jeongchaeke gwanhan yeongu 한국의 도서관 발전을 위한 국가 정책에 관한 연구 (A Study of National Policy for Library Development in Korea). Seoul: Ehwa Womans University.

Lee Byeong Seok et. al. 이병석 외. 2012. Isibil segi jisik jeongbo gukgareul wihan gukga doseogwan ganui sangho hyeopryeok 21세기 지식정보 국가를 위한 국가도서관간의 상호협력 (Mutual Cooperation among National Libraries for the $21^{\text {st }}$ Century Knowledge Information State). Organiser: National Assembly Library. June 28.

Lee Chang Se 이창세. 1969. "Guklip jungang doseogwanui eoje oneul naeil 국립중앙도서관의 어제 오늘 내일 (Past, Present and Future of National Library of Korea)." Doseogwan 도서관 24 (6): 5-10. 
Lee Chul Kyu 이철규. 1962. "Doseogwan haengjeongui bigyo yeongu 도서관 행정의 비교 연구 (Comparative Study of Library Administration).” Master thesis, Seoul National University.

—. 1965. "Seonjin jegugui doseogwan jeongchaek 선진제국의 도서관 정책 (Library Policy of Developed Countries)." National Assembly Library Review 국회도서관보 2(10): 10-21.

Lee Chun Hi 이춘희.1974. "Gughoe doseogwane baranda 국회도서관에 바란다 (Expectations from the National Assembly Library)." National Assembly Library Review 국회도서관보 100: 25-26.

Lee Jee Yeon 이지연. 2012. "Gukgajeok sujuneseo doseogwan hyeopryeogui jungyoseonggwa banghyang jeeon 국가적 수준에서 도서관 협력의 중요성과 방향 제언 (Importance of Library Cooperation and Direction on a National Level)." National Assembly Library Review 국회도서관보 49(7): 16-23.

Lee Myeong-Hee 이명희, and Lee Sang-Loel 이상렬. 2002. "Gukga daepyo jeonja doseogwan websaiteuui pyeonggae gwanhan yeongu 국가대표전자도서관 웹사이트의 평가에 관한 연구 (A Study of the Evaluation of Websites of Three National Assembly Libraries)." National Assembly Library Review 국회도서관보 39(3): 3-21.

Lee Pil Jae 이필재. 1980. "Urinara gugga jungang doseogwan seolchi banghyang 우리나라 국가중앙도서관의 설치방향 (Establishment of the National Central Library in Korea)." Yeongu nonchong 연 구논총1: 151-216.

Lee Taek Jun 이택준. 1980. "Doseogwanbeop gaejeonge gwanhan sogo 도서관법개정방향에 관한 소고 (A Study of Library Act Amendment)." Doseogwan 도서관 35(8): 14-18.

Lee Seung Ju 이승주. 1970. "Gukga jungang doseogwan jedoui yeongu 국가중앙도서관제도의 연구 (A Study of National Central Library System)." Doseogwan 도서관 150: 13-29.

—. 1974. "Guklip doseogwane daehan gakseo 국립도서관 논의에 대한 각서 (Notes on Disputes on the National Library)." Doseogwan 도서관 29(6): 42-48.

Ministry of Culture 문화부. 1990. Gonggong doseogwanbeop gaejeong(an) 공공도서관법 개정(안) (Public Libraries Act Amendment). Seoul: Ministry of Culture. (Official Archives: Document Management Number of National Archives of Korea BA 0756822).

National Assembly Library 국회도서관. Accessed July 28, 2014. http://dl.nanet.go.kr/index.do.

—. 2005. Gukhoe doseogwan baljeon banghyang 국회도서관 발전 방향 (National Assembly Library's Development Direction). 국회도서관 정책 세미나 Gughoe doseogwan jeongchaek semina. Organizer and location: National Assembly Library. 
—. 2012. National Assembly Library 60 years 1952-2012 국회도서관 60년사 19522012. Seoul: National Assembly Library.

National Library of Korea 국립중앙도서관. Accessed July 28, 2014. http://www.nl.go.kr/english/index.jsp

—. 1966. "Jwadam: guklib jungang doseogwaneul malhanda 좌담: 국립중앙도서관을 말한다 (Discussion: Reference to National Library of Korea)." Doseogwan 도서관 (Library) 21(1): 14-18.

—. 1973. Guglib jungang doseogwan sa 국립중앙도서관사 (The History of the National Library of Korea). Seoul: Korea National Library.

National Library of Korea 국립중앙도서관. 1975. Doseogwan beob gwangye jaryo 도서관법관계자료 (Library Act Materials). Seoul: National Library of Korea. [Unpublished document]

- 2006. The History of the National Library of Korea, Sixty years 국립중앙도서 관 60년사. Seoul: National Library of Korea.

OED (Oxford English Dictionary). Accessed, July 27, 2014. http://www.oed.com/.

Oh Dong Woo 오동우. 1988. "Urinara doseogwan jeongchaekui dangmyeon gwajewa baljeon bangan 우리나라 도서관 정책의 당면 과제와 발전방안 (Future Issues and the Development Plan of Library Policy in Korea)." National Assembly Library Review 국회도서관보 25(2): 5-16.

Supreme Council for National Reconstruction 국가재건최고회의. 1962. Doseogwan gwangye ipbeob chamgo jaryo:gugrib jungang doseogwan seolchi munjereul jungsimeuro 도서관관계입 법참고자료:국립중앙도서관설치 문제를 중심으로 (Library References for the Purpose of Legislation: Focus on the Establishment of National Central Library). [Unpublished document] Seoul: Supreme Council for National Reconstruction.

The British Library Board. "About Us.” Accessed July 272014. http:/www.bl.uk/aboutus/quickinfo/facts/history/.

Yun Yeo Taek 윤여택. 1966. “Guklib jungang doseogwanui imiji 국립중앙도서관의 이미지 (Impression of the National Central Library)." KLA Bulletin 도서관문화 7(7): 2-8.

—. 1969. Gukhoe doseogwanui baljeon chaek: gukgaui jungang doseogwangwa gwanryeonhayeo 국회도서관의 발전책: 국가의 중앙도서관과 관련하여 (National Assembly Library Development Plan: In Reference to the Country's Central Library). Seoul: National Assembly Library.

—. 1975. "Gukgadoseogwan 국가도서관 (National Library)." National Assembly Library Review 국회도서관보 107: 18-26. 
RYU Hyeonsook: Examination of Disputes

Yun Young Dae 윤영대. 1978. "Urinara doseogwan jeongchegui hyeonhwang 우리나라 도서관 정책의 현황 (Present Situation of Library Policy in Korea).” KLA Bulletin 도서관문화 19(8): 4-6. 